\title{
AKUNTABILITAS SELEKSI TERBUKA JABATAN PIMPINAN TINGGI PRATAMA SEKRETARIS DAERAH KABUPATEN BLORA
}

\author{
M. Aminudin \\ Fakultas Ilmu Administrasi, Universitas Brawijaya, email zakysw@gmail.com \\ Sumartono dan Tjahjanulin Domai \\ Fakultas Ilmu Administrasi, Universitas Brawijaya
}

\begin{abstract}
Abstrak
Mekanisme pengisian jabatan struktural yang lebih relevan atas nilai akuntabilitas dan meritokrasi adalah dengan seleksi terbuka. UU Nomor 5 Tahun 2014 tentang Aparatur Sipil Negara mewajibkan pengisian Jabatan Pimpinan Tinggi yang lowong menggunakan sistem tersebut, karenanya Pemerintah Kabupaten Blora melaksanakan seleksi terbuka untuk mengisi Jabatan Pimpinan Tinggi Pratama Sekretaris Daerah. Penelitian ini bertujuan untuk menganalisis unsur akuntabilitas prosedural seleksi terbuka jabatan pimpinan tinggi pratama Sekretaris Daerah Kabupaten Blora. Pendekatan yang digunakan adalah kualitatif dengan analisis deskriptif. Metode pengumpulan data menggunakan wawancara, dokumentasi korespondensi dan peraturan. Hasil penelitian menunjukkan tahap demi tahap pengisian jabatan melalui seleksi terbuka sejak pembentukan panitia seleksi, penetapan standar kompetensi, seleksi kompetensi, penelusuran rekam jejak, wawancara, pengumuman hasil seleksi bahkan koordinasi dengan Gubernur dan Komisi ASN telah akuntabel dengan memenuhi kaidah peraturan perundangan, yaitu UU Nomor 5 Tahun 2014 tentang Aparatur Sipil Negara dan PermenPAN RB Nomor 13 Tahun 2014 tentang Tatacara Pengisian Jabatan Pimpinan Tinggi Secara Terbuka di Lingkungan Instansi Pemerintah.
\end{abstract}

Kata Kunci: Akuntabilitas, Seleksi Terbuka, Jabatan Pimpinan Tinggi Pratama

\begin{abstract}
Mechanism more relevant to fill structural positions on the value of accountability and meritocracy is open selection. Law No. 5 of 2014 concerning the State Civil Apparatus require the completion of High vacant leadership positions using the system, therefore Blora District Government to implement an open selection to fill leadership positions High Primary Regional Secretary. This study aimed to analyze the elements of procedural accountability of leadership positions open selection of Blora District Secretary. The approach used is qualitative descriptive analysis. Methods of data collection using interviews, documentation, correspondence and normative literature. The results showed step by step filling the position through an open selection since the formation of the selection committee, the establishment of standards of competence, the selection of competence, search the track record, the interview, the announcement of the selection results even coordination with the Governor and the Commission ASN has been accountable to fulfill the norms of legislation, namely Law No. 5 of 2014 concerning the State Civil Apparatus and PERMENPAN RB No. 13 Year 2014 regarding the Procedures Completion of High Leadership Position Openly in Environment Government Agencies.
\end{abstract}

Keywords: Accountability, Open Selection, Leadership Position High Primary

\section{PENDAHULUAN}

Kepala Daerah meliputi berbagai resources, tak terkecuali birokrasi. Hal ini tercermin dari Kepala Daerah sebagai Pejabat Pembina Kepegawaian di daerah. Konsekuensinya, kewenangan dalam hal pengangkatan , pemindahan dan pemberhentian mutlak berada di tangan Kepala Daerah.

Secara filosofis, sub ordinasi birokrasi oleh pejabat politik dimaksudkan untuk menyeimbangkan inklusifitas birokrasi. Ada kehadiran rakyat yang menyusup dalam tubuh birokrasi melalui representasi Kepala Daerah yang dipilih langsung. Sayangnya, amanah atau yang lebih lazim dimaknai kewenangan sering kali bertolak belakang dengan semangat filosofi yang dibangun. Kewenangan, potensial disalahgunakan dengan menempatkan pejabat struktural dalam pos strategis hanya karena faktor like and dislike. Tidak berdasarkan the right man on the right place, tetapi berdasarkan klik atau patron (Istianto, 2011:2018).

Mekanisme pengangkatan PNS dalam jabatan struktural diatur dalam Peraturan Pemerintah Nomor 100 tahun 2000 sebagaimana diubah dengan Peraturan Pemerintah Nomor 13 Tahun 2002 tentang Pengangkatan Pegawai Negeri Sipil dalam Jabatan Stuktural. Namun, aturan tersebut belum menekankan kompetensi dan 
kinerja dalam manajemen kepegawaian, sehingga dalam praktiknya diketemukan bahwa kepangkatan (senioritas) dan kedekatan politik / favoritisme / patronase menjadi syarat yang menentukan pengisian jabatan atau dimaknai closed career system (Prasojo, 2014:15). Implikasinya, rotasi di tubuh birokrasi berpotensi KKN (Sudrajat, 2014:62).

Aspek akuntabilitas menjadi dimensi yang belum tersentuh dalam proses pengisian jabatan struktural di daerah. Tanpa mengesampingkan peran subtantif Badan Pertimbangan Jabatan dan Kepangkatan (Baperjakat) sebagai filter bagi Kepala Daerah untuk menunaikan kekuasaan dalam menempatkan jajaran dibawahnya, sekali lagi bahwa pengisian yang bersifat tertutup dan inklusif berdampak pada pengabaian ketaatan institusional dan profesionalitas atas dasar visi dan misi organisasi dan tujuan pelayanan (Kausar, 2009:9).

Minimnya akuntabilitas pengisian jabatan struktural mendekonstruksi rasionalitas tatanan pemerintah daerah. Semakin merisaukan apabila permisifitas atas gejala ini statis tanpa ada suatu perubahan fundamental. Tidak ingin terjebak lebih dalam, katalis perubahan itu dimandatkan melalui instrumentasi penerbitan Undang-Undang Nomor 5 Tahun 2014 tentang Aparatur Sipil Negara. Upaya ini menciptakan konsep baru dalam pengisian jabatan yang berorientasi pada akuntabilitas dan berbasis merit (Sudrajat, 2014:62). Antitesis dari inklusifitas pengangkatan pejabat struktural, adalah promosi melalui prosedur seleksi. Para kandidat yang akan dipromosikan dihimpun, lalu dipilih melalui mekanisme seleksi sesuai kualifikasi yang ditetapkan (Ardana, et.al, 2011:109). Tujuan penelitian ini adalah untuk mendeskripsikan dan menganalisis proses seleksi terbuka Jabatan Pimpinan Tinggi Pratama Sekretaris Daerah Kabupaten Blora dari perspektif akuntabilitas prosedural.

\section{METODE}

Penelitian ini menggunakan pendekatan kualitatif dengan analisis deskriptif. Fokus penelitian adalah proses seleksi terbuka jabatan pimpinan tinggi Sekretaris Daerah Kabupaten Blora, yang meliputi:

1. Tahapan Persiapan : pembentukan panitia seleksi, penyusunan dan penetapan standar kompetensi jabatan yang lowong, dan;

2. Tahap Pelaksanaan : pengumuman jabatan yang lowong, seleksi administrasi, seleksi kompetensi (penilaian kompetensi manajerial dan bidang, penelusuran rekam jejak, wawancara akhir, pengumuman hasil seleksi), koordinasi dengan Gubernur dan Koordinasi dengan Komisi Aparatur Sipil Negara (KASN).
Pengumpulan data dilakukan melalui wawancara mendalam dengan informan kunci, yaitu Kepala BKD Kabupaten Blora, selaku sekretaris panitia seleksi terbuka dan beberapa PNS BKD Kabupaten Blora, khususnya dalam kapasitas sebagai anggota sekretariat panitia seleksi promosi terbuka dan dokumentasi korespondensi serta aturan operasional.

\section{HASIL DAN PEMBAHASAN}

Secara administratif prosedural, tatacara pengisian JPT secara terbuka di lingkungan instansi pemerintah diatur dalam PermenPAN RB Nomor 13 Tahun 2014. Selanjutnya, tatacara seleksi pengisian jabatan pimpinan tinggi pratama dilaksanakan dengan tahapan sebagai berikut:

\section{Persiapan}

\section{a. Pembentukan panitia seleksi oleh Pejabat Pembina Kepegawaian}

1) Panitia seleksi terdiri dari unsur:

a) Pejabat terkait dari lingkungan instansi yang bersangkutan;

b) Pejabat dari instansi lain yang terkait dengan bidang tugas jabatan yang lowong;

c) Akademisi/pakar/profesional.

2) Panitia seleksi memenuhi persyaratan:

a) Memiliki pengetahuan dan/atau pengalaman sesuai dengan jenis, bidang tugas, dan kompetensi jabatan yang lowong; dan;

b) Memiliki pengetahuan umum mengenai penilaian kompetensi.

3) Panitia seleksi berjumlah ganjil yaitu paling sedikit 5 orang dan paling banyak 9 orang.

4) Perbandingan anggota panitia seleksi berasal dari internal paling banyak $45 \%$.

5) Panitia seleksi melaksanakan seleksi dapat dibantu oleh Tim Penilai Kompetensi (assesor) yang independen dan memiliki pengalaman dalam membantu seleksi Pejabat Pemerintah.

Dalam tahap ini, Pejabat Pembina Kepegawaian Kabupaten Blora mendistribusikan bagian dari kewenangannya pada panitia seleksi. Mendasari ketentuan persyaratan dan unsur keanggotaan, panitia seleksi terdiri dari 5 orang anggota yang terdiri dari 2 orang Pakar dengan latar belakang masing-masing mantan Wakil Bupati sebagai Ketua Pansel dan Mantan Sekretaris Daerah sebagai anggota yang kedua-duanya tidak terkait langsung dengan pemerintah saat ini, 1 orang akademisi sebagai anggota dan 2 orang dari internal instansi, masing-masing sebagai sekretaris dan anggota.

Komposisi dan kualifikasi panitia seleksi Jabatan Pimpinan Tinggi Pratama Sekretaris Daerah telah memenuhi ketentuan yang berlaku. Jumlah panitia telah 
berjumlah ganjil dengan jumlah minimal, yaitu 5 (lima) orang. Komposisi dari internal instansi sejumlah $2 / 5$ atau $40 \%$, kurang dari $45 \%$. Selanjutnya, dari sisi kualifikasi masing-masing personil panitia secara umum memahami bidang pemerintahan dengan latar belakang yang relevan. Poin krusial lain yang perlu digarisbawahi adalah Ketua Panitia Seleksi yang berasal dari luar instansi cukup mencerminkan Independensinya. Artinya, tahapan persiapan pertama telah memenuhi akuntabiliats prosedural.

\section{b. Penyusunan dan penetapan standar kompetensi jabatan yang lowong}

Penetapan standar kompetensi mendasari hasil analisis jabatan Sekretaris Daerah yang ditetapkan dengan Keputusan Kepala Daerah:

Tabel 1. Syarat jabatan Sekretaris Daerah

\begin{tabular}{|c|c|c|}
\hline No & Unsur & Uraian \\
\hline 1 & Pangkat & Pembina Utama Muda (IV/c) \\
\hline 2 & $\begin{array}{l}\text { Pengetahuan } \\
\text { kerja }\end{array}$ & $\begin{array}{l}\text { Good } \quad \text { Governance } \\
\text { Pengelolaan Keuangan Daerah }\end{array}$ \\
\hline 3 & Keterampilan & $\begin{array}{l}\text { Kepemimpinan, Koordinasi, Perencanaan } \\
\text { dan Pengambilan Keputusan }\end{array}$ \\
\hline 4 & $\begin{array}{l}\text { Pendidikan } \\
\text { formal }\end{array}$ & Minimal Strata 1 (S1) \\
\hline 5 & $\begin{array}{l}\text { Pelatihan/ } \\
\text { kursus }\end{array}$ & Diklat PIM II \\
\hline 6 & $\begin{array}{l}\text { Pengalaman } \\
\text { kerja }\end{array}$ & $\begin{array}{l}\text { Pengalaman pada jabatan yang lebih } \\
\text { rendah minimal } 4 \text { tahun }\end{array}$ \\
\hline 7 & Bakat kerja & Intelegensia, ketelitian, verbal, numerik \\
\hline 8 & $\begin{array}{l}\text { Temperamen } \\
\text { kerja }\end{array}$ & $\begin{array}{l}\text { Kemampuan menyesuaikan diri menerima } \\
\text { tanggungjawab untuk kegiatan } \\
\text { memimpin, mengendalikan, atau } \\
\text { merencanakan } \\
\text { kemampuan menyesuaikan diri untuk } \\
\text { pekerjaan-pekerjaan mempengaruhi orang } \\
\text { lain dalam pendapat, sikap atau } \\
\text { pertimbangan mengenai gagasan, } \\
\text { kemampuan menyesuaikan diri dengan } \\
\text { kegiatan pengambilan kesimpulan, } \\
\text { pembuatan pertimbangan, atau pembuat } \\
\text { peraturan/keputusan berdasarkan kriteria } \\
\text { yang diukur atau yang dapat diuji. }\end{array}$ \\
\hline 9 & Minat kerja & $\begin{array}{l}\text { Pilihan melakukan kegiatan yang } \\
\text { berhubungan dengan komunikasi data, } \\
\text { pilihan melakukan kegiatan yang bersifat } \\
\text { ilmiah dan teknis, pilihan melakukan } \\
\text { kegiatan yang bersifat abstrak dan kreatif, } \\
\text { pilihan melakukan kegiatan yang } \\
\text { berhubungan dengan mesin dan teknik, } \\
\text { pilihan melakukan kegiatan yang } \\
\text { menghasilkan kepuasan nyata dan dengan } \\
\text { proses }\end{array}$ \\
\hline 10 & Kondisi fisik & $\begin{array}{lccc}\text { Jenis } & \text { kelamin: } & \text { Pria atau } & \text { wanita } \\
\text { Umur: } & 45 & \text { tahun } & \text { keatas } \\
\text { Penampilan: Rapi } & & & \end{array}$ \\
\hline
\end{tabular}

Sumber: Keputusan Bupati Blora Nomor: 780/1772/2013

Penggunaan kompetensi dalam seleksi dapat meningkatkan kemungkinan orang-orang yang direkrut akan sukses dalam pekerjaannya (Manopo, 2011:90). Standar kompetensi secara umum telah ditetapkan melalui analisis jabatan. Analisis jabatan akan membantu proses seleksi dalam mengidentifikasi para kandidat yang paling berkualifikasi, karena selain terdapat uraian tugas, tercantum pula spesifikasi jabatan (Noe, et.al, 2010:209). Spesifikasi jabatan merupakan pengetahuan, ketrampilan, kemampuan dan karakteristik lainnya yang harus dimiliki seorang individu agar dapat menjalankan pekerjaanya (Wahjono, 2015:56). Pengetahuan mengacu pada informasi faktual atau prosedural yang diperlukan untuk berhasil menjalankan tugas. Ketrampilan merupakan tingkat kecakapan individu dalam melaksanakan tugas tertentu. Kemampuan mengacu pada kemampuan bertahan secara lebih umum yang dimiliki seorang individu. Sedangkan karakteristik lainnya dapat berupa ciri-ciri kepribadian seperti motivasi prestasi atau kegigihan seseorang. Sebagai salah satu prosedur yang harus dilalui sebelum proses seleksi, analisis jabatan yang menghasilkan spesifikasi jabatan telah terpenuhi dan digunakan sebagai acuan dalam menentukan standar kompetensi dalam proses seleksi terbuka JPT Sekretaris Daerah Kabupaten Blora. Artinya, akuntabilitas prosedural pada aras persiapan, baik saat pembentukan panitia dan penetapan standar kompetensi telah tercukupi.

\section{Pelaksanaan}

\section{a. Pengumuman Jabatan yang lowong}

Pengumuman jabatan yang lowong harus memenuhi ketentuan:

1) Diumumkan secara terbuka dalam bentuk surat edaran melalui papan pengumuman, dan/atau media cetak, media elektronik (termasuk media online/internet).

2) Pengumuman dilaksanakan paling kurang 15 (lima belas) hari kerja sebelum batas akhir tanggal penerimaan lamaran.

3) Pada instansi Pemerintah Kabupaten/Kota dilakukan dengan cara:

a) Untuk mengisi jabatan pimpinan tinggi pratama dilakukan secara terbuka dan kompetitif paling kurang pada tingkat Kabupaten/Kota yang bersangkutan, dan/atau antar Kabupaten/Kota dalam satu Provinsi;

b) Pengisian jabatan pimpinan tinggi pratama pada instansi Pemerintah Kabupaten/Kota dilakukan secara terbuka dan kompetitif di kalangan PNS dengan memperhatikan syarat kompetensi, kualifikasi, kepangkatan, pendidikan dan latihan, rekam jejak jabatan, dan integritas, serta persyaratan lain yang dibutuhkan sesuai dengan ketentuan peraturan perundang-undangan.

4) Dalam pengumuman tersebut harus memuat:

a) Nama jabatan yang lowong;

b) Persyaratan administrasi antara lain:

(1) Surat lamaran dibuat sendiri oleh pelamar dan bermaterai; 
(2) Fotokopi SK kepangkatan dan jabatan yang diduduki;

(3) Forokopi ijazah terakhir yang sesuai dengan jabatan yang dilamar;

(4) Fotokopi SPT tahun terakhir;

(5) Fotokopi hasil penilaian prestasi kerja 2 tahun terakhir;

(6) Riwayat hidup (CV) lengkap.

c) Persyaratan integritas yang dibuktikan dengan penandatanganan pakta integritas;

d) Batas waktu penyampaian lamaran dan pengumpulan kelengkapan administrasi;

e) Tahapan, jadwal, dan sistem seleksi;

f) Alamat atau nomor telepon sekretariat panitia seleksi yang dapat dihubungi;

g) Prosedur lain yang diperlukan;

h) Persyaratan jenjang pendidikan dan sesuai dengan bidang jabatan yang lowong;

i) Pengalaman jabatan terkait dengan jabatan yang dilamar minimal 5 tahun;

j) Lamaran disampaikan kepada panitia seleksi;

k) Pengumuman ditandatangani oleh ketua panitia seleksi atau ketua tim sekretariat panitia seleksi atas nama ketua panitia seleksi.

Pengumuman seleksi calon Pimpinan Tinggi Pratama Sekretaris Daerah Kabupaten Blora diterbitkan pada 5 Desember 2014 dengan Nomor: Pansel/PTP.1/02/2014. Dalam surat pengumuman tersebut, telah memuat ketentuan umum, ketentuan khusus, tahapan seleksi, dan ketentuan lain-lain. Syarat substantif diatur dalam ketentuan umum yang mensyaratkan PNS yang berhak mengikuti seleksi sebagai berikut:

(1) Berstatus sebagai Pegawai Negeri Sipil Daerah Kabupaten Blora;

(2) Sekurang-kurangnya telah menduduki jabatan struktural Eselon II. b selama 2 (dua) tahun dan pernah menduduki jabatan Eselon II.b yang berbeda;

(3) Berusia setinggi-tingginya 57 (lima puluh tujuh) tahun per 1 Pebruari 2015;

(4) Kualifikasi pendidikan akademik minimal Strata 1 (S1);

(5) Telah mengkuti dan lulus diklat kepemimpinan tingkat II atau yang setara;

(6) Semua unsur penilaian prestasi kerja / DP-3 sekurang-kurangnya bernilai baik dalam 2 (dua) tahun terakhir;

(7) Tidak sedang menjalani hukuman disiplin tingkat sedang atau berat;

(8) Memiliki kompetensi jabatan yang diperlukan;

(9) Sehat jasmani dan rohani;
(10) Bersedia membuat rencana strategis sebagai calon Pejabat Pimpinan Tinggi Pratama Sekretaris Daerah.

Berdasarkan ketentuan umum, seleksi terbuka dilaksanakan secara internal di lingkup Pemerintah Kabupaten Blora. Hal ini sudah sesuai ketentuan yang berlaku bahwa untuk jabatan pimpinan tinggi pratama paling kurang dilaksanakan pada tingkat Kabupaten/Kota yang bersangkutan. Dari sisi akuntabilitas prosedural dapat dikatakan terpenuhi karena pengumuman telah memuat ketentuan umum dan administrasi, secara substantif tidak diskriminatif, diumumkan secara terbuka, dan dari sisi legalitas telah sesuai dengan aturan normatifnya.

\section{b. Seleksi Administrasi}

Ketentuan Seleksi Administrasi adalah:

1. Penilaian terhadap kelengkapan berkas administrasi yang mendukung persyaratan dilakukan oleh Sekretariat Panitia Seleksi;

2. Penetapan minimal 3 (tiga) calon pejabat pimpinan tinggi yang memenuhi persyaratan administrasi untuk mengikuti seleksi berikutnya untuk setiap 1 (satu) lowongan jabatan pimpinan tinggi;

3. Kriteria persyaratan administrasi didasarkan atas peraturan perundang-undangan dan peraturan internal instansi yang ditetapkan oleh Pejabat Pembina Kepegawaian masing-masing;

4. Syarat yang harus dipenuhi adalah keterkaitan objektif antara kompetensi, kualifikasi, kepangkatan, pendidikan dan latihan, rekam jejak jabatan, dan integritas serta persyaratan lain yang dibutuhkan oleh jabatan yang akan diduduki;

5. Dapat dilakukan secara online bagi pengumuman pelamaran yang dilakukan secara online;

6. Pengumuman hasil seleksi ditandatangani oleh Ketua Panitia Seleksi.

Dalam tahapan seleksi administrasi, terdapat 6 (enam) PNS yang mendaftar dan setelah melalui verifikasi dan validasi, semuanya dinyatakan lolos seleksi administrasi. Artinya, hasil seleksi administrasi yang dilakukan oleh sekretariat Panitia Seleksi cukup memenuhi ketentuan minimal untuk dapat dilanjutkan ke proses seleksi kompetensi. Dengan jumlah ketentuan minimal 3 (tiga) PNS diharapkan tumbuh rasa kompetisi sehingga seleksi ini dapat credible. sekretariat panitia seleksi telah melaksanakan setiap tahapan seleksi administrasi sesuai ketentuan yan berlaku. Artinya, akuntabilitas prosedural tercukupi.

\section{c. Seleksi Kompetensi}

Seleksi kompetensi terdiri dari beberapa tahapan, yaitu:

1) Penilaian Kompetensi Manajerial dan Kompetensi Bidang 
Pelaksanaan kompetensi manajerial dan Kompetensi Bidang menggunakan metode Position Competencies Assesment Program (PCAP). Dalam proses seleksi tersebut bekerjasama dengan assesor dari Pemerintah Provinsi Jawa Tengah. Adapun hasil dari tes ini adalah 4 (empat) peserta dinyatakan Masih Memenuhi Syarat (MMS) dan 2 (dua) peserta dinyatakan Kurang Memenuhi Syarat (KMS).

2) Penelusuran rekam jejak

Hal ini dilakukan dengan menelusuri rekam jejak jabatan dan pengalaman yang relevan dengan jabatan yang dilamar, disamping menelusuri rekam jejak kepribadian melalui atasan, rekan sejawat, dan bawahan serta lingkungannya. Penelusuran ini dilaksanakan secara tertutup, obyektif, dan dilaksanakan oleh personil yang memiliki kemampuan dan pengetahuan teknis inteligen.

3) Wawancara Akhir

Berdasarkan ketentuan, Panitia Seleksi melaksanakan wawancara akhir dengan materi wawancara terstandar sesuai jabatan yang dilamar, bersifat klarifikasi/pendalaman terhadap pelamar yang mencakup peminatan, motivasi, perilaku dan karakter. Dari 4 (empat) peserta, kesemuanya mengikuti proses wawancara. Adapun wawancara ini bertujuan untuk mengetahui tingkat kemampuan seorang calon Pimpinan Tinggi dalam menghadapi tekanan, mengendalikan bawahan, kultur budaya Blora serta kematangan dalam pengambilan keputusan.

4) Pengumuman Hasil Seleksi

Tahapan ini merupakan tahapan akhir dari tugas Panitia Seleksi. Dalam surat pengumuman Panitia Seleksi Nomor : Pansel/PTP.I/15/2015 terkait hasil seleksi mengerucut pada 3 (tiga) orang terbaik mendasari kalkulasi nilai dari tiap-tiap tahapan.

Akuntabilitas dari tahapan seleksi kompetensi setidaknya dapat ditelusuri dari perspektif pelaksana penilaian oleh lembaga independen dan metode yang digunakan untuk menilai kompetensi yang meliputi unsur: analisis, kecepatan biltus, ketepatan biltus, intrapreneurship, inisiatif, jejaring strategis, kemampuan komunikasi, kemampuan presentasi, toleransi terhadap stress, pemikiran visioner, kepemimpinan, perencanaan dan pengorganisasian, pengawasan dan pengendalian serta delegasi. Selanjutnya penelusuran rekam jejak untuk mengetahui integritas dan moralitas menggunakan metode $360^{\circ}$, yang dimaknai bahwa penelusuran rekam jejak seseorang kepada atasan, bawahan, rekan sejawat dan atau lingkungannya. Penilian semacam ini akan memperkaya khasanah dan obyektivitas penilaian. Hasil akhir penilaian merupakan kompilasi atas masing-masing unsur dengan bobot tertentu, yang kemudian diranking dan direkomendasikan secara prioritas mendasari hasil penilaian kepada Pejabat Pembina Kepegawaian melalui Pejabat yang berwenang.

\section{d. Koordinasi dengan Gubernur}

Mengingat JPT yang diisi adalah Sekretaris Daerah, maka PPKD wajib berkoordinasi dengan Gubernur. Melalui surat Nomor 821.2/369/2015 tanggal 5 Februari 2015, PPKD berkoordinasi dengan maksud mendapatkan tindak lanjut atas hasil seleksi. Berselang lebih dari satu bulan, tepatnya 20 Maret 2015, Gubernur melaui surat Nomor 005/141.Rhs merespon surat terkait dengan menghimbau PPKD hadir dan menugaskan 3 (tiga) Calon Pejabat Pimpinan Tinggi Sekda guna memaparkan rencana strategis di dalam sidang Baperjakat Provinsi Jawa Tengah yang diselenggarakan pada Senin, 23 Maret 2015. Selanjutnya hasil koordinasi ini tertuang dalam Surat Gubernur Nomor 021/1719.Rhs tertanggal 30 Maret 2015 yang pada intinya menyetujui hasil seleksi dan selanjutnya dapat ditindaklanjuti dengan penetapan keputusan pelantikan sesuai ketentuan perundangundangan yang berlaku.

Sebagai amanat UU ASN, Pemerintah Kabupaten Blora, telah berkoordinasi dengan tingkat pemerintahan yang lebih tinggi, yaitu Gubernur selaku wakil pemerintah di daerah. Artinya, tahapan koordinasi telah dijalankan sesuai prosedur dan kaidah perundangan, sehingga akuntabilitas prosedural terpenuhi.

\section{e. Laporan proses kepada Komisi Aparatur Sipil Negara (KASN)}

Proses koordinasi dengan KASN dilaksanakan dalam jeda koordinasi dengan Gubernur. Melalui Surat Bupati Nomor 800/0529 tertanggal 27 Februari 2015 kepada KASN, dimana secara substantif menerangkan proses pengisian JPT Sekda dari awal hingga proses terakhir saat surat tersebut disusun. Selanjutnya, melalui surat KASN Nomor: B/160/KASN/3/2015 bertanggal 16 Maret 2016, KASN mengapresiasi laporan yang disampaikan kepada KASN, dan menyatakan proses seleksi telah memenuhi persyaratan. Sebagai penjamin pelaksanaan akuntabilitas dan meritokrasi dalam proses seleksi, rekomendasi dari KASN cukup menguatkan bahwa tahap demi tahap yang dilaksanakan oleh Pemerintah Kabupaten Blora dalam menyeleksi Calon Pimpinan Tinggi Pratama Sekretaris Daerah telah akuntabel secara prosedur

\section{PENUTUP}

\section{Simpulan}

Berdasarkan penelitian dan hasil pembahasan, peneliti menarik kesimpulan:

1. Dalam tahapan persiapan seleksi yang meliputi pembentukan panitia seleksi dan penyusunan dan penetapan standar kompetensi telah memenuhi kriteria akuntabilitas prosedural: 
a. Panitia seleksi memiliki latar belakang yang relevan dengan pengalaman di pemerintahan daerah dan independen karena didominasi dari luar pemerintahan;

b. Penetapan standar kompetensi diperoleh berdasarkan hasil analisis jabatan.

2. Dalam tahapan pelaksanaan seleksi yang meliputi: pengumuman jabatan yang lowong, seleksi administrasi, seleksi kompetensi (penilaian kompetensi manajerial dan bidang, penelusuran rekam jejak, wawancara akhir, pengumuman hasil seleksi), koordinasi dengan Gubernur dan Koordinasi dengan Komisi Aparatur Sipil Negara (KASN) memenuhi kriteria akuntabilitas prosedural karena masing-masing tahapan dilaksanakan sesuai dengan ketentuan yang berlaku

\section{DAFTAR PUSTAKA}

Ardana, I Komang, et.al. (2012). Manajemen Sumber Daya Manusia. Yogyakarta: Graha Ilmu.

Hinton, P and Wilson, E (1993). Accountability. Eds. Public Services in 1990. Wirral: Tudor Business Publications.

Istianto, Bambang. (2011). Demokratisasi Birokrasi. Jakarta: Mitra Wacana Media.
Kausar AS, (2009). Sistem Birokrasi Pemerintahan di Daerah dalam Bayang-bayang Patron-Klien. Bandung: Alumni.

Manopo, Christine. (2011). Competency Based Talent and Performance Management System. Jakarta: Salemba Empat.

Noe, Raymond. A, et.al. (2010). Manajemen Sumber Daya Manusia: Mencapai Keunggulan Bersaing. Jakarta: Salemba Empat.

Shafritz, Jay M and E.W Russel. (1997). Introducing Public Administration. New York: Longman.

Prasojo,Eko. (2014). Undang-Undang Aparatur Sipil Negara: Membangun Profesionalisme Aparatur Sipil Negara. Dalam Jurnal Kebijakan dan Manajemen PNS, Vol.8 No.1, hal.13-29.

Sudrajad, Tedi. (2014). Eksistensi Kebijakan Pengisian Jabatan Struktural dalam Kerangka Pengembangan SDM Aparatur Berbasis Merit. Jurnal Kebijakan dan Manajemen PNS, Vol.8 No.1, hal.61-71.

Wahjono, Sentot Imam. (2015). Manajemen Sumber Daya Manusia. Jakarta: Salemba Empat.

Andangatmadja, Andi. (2012). Analisis Akuntabilitas Program Bantuan Pembangunan Ruang Laboratorium IPA pada Sekolah Menengah Pertama di Kabupaten Gresik Jawa Timur. Tesis Magister Administrasi, Universitas Indonesia Jakarta. 